\title{
Organizational-and-methodical support of sustainable development strategy in the medical sphere
}

\author{
Asiyat Mottaeva ${ }^{1, *}$ \\ ${ }^{1}$ Moscow State University of Civil Engineering, Yaroslavskoe shosse, 26, Moscow, 129337, Russia
}

\begin{abstract}
The article presents the analysis of the market of the medical services as well as identification of the problems, interfering high quality functioning of the Municipal Healthcare system. The research of the existing approaches and methods of creation and implementation of the development strategy for the organizations in the medical sphere was conducted. Some provisions for the increase in the efficiency of functioning of the organizations in the medical sphere mere offered by the author. There is no doubt, that some new management approaches are desirable. The author has developed some recommendations for the improvement of the processes of development and introduction of the development strategy for the organizations in the medical sphere. The author also considers the matters of information support of the processes of development and introduction of the development strategy of the medical organizations.
\end{abstract}

\section{Introduction}

Nowadays the creation and introduction of the development strategy is the fundamental point in management of the medical organization, which has to provide its sustainable economic growth and development, as well as the increase in competitiveness of the services offered.

Effective long-term work of any organization of the medical sphere, its economic growth and development are determined by a proper choice of the strategic reference points, allowing the best use of the potential human capital and other resources. That is impossible without development and implementation of any strategy, as it is necessary to consider the programme, the plan, the general course of the subject of management for the achievement of strategic objectives.

In the conditions of tough competition and quickly changing situation the organizations have to develop long-term strategy of their behaviour, which would allow them to keep up with the changes happening in their the external environment.

Many reasons have led to the sharp increase in the value of strategic management in the system of effective management of the medical organizations. They include: the acceleration of changes in the environment, emergence of new inquiries and change of the

\footnotetext{
${ }^{*}$ Corresponding author: asya@front.ru
} 
consumer' position, competition growth, business internationalization, achievements in science and technology, development of information networks, wide availability of modern technologies, change of the human resources role and so on $[1,2,3]$.

It is possible to name some Russian authors, considering theoretical and methodological matters of the development strategy of the organization: Azoyev G.L., Barinov V. A., Vesnin V.R., Vikhansky O.S., Gaponenko A.L., Pankrukhin A.P., etc. It is also possible to remind such foreign scientists as Thompson A.A., Strickland A. J., Lamben Jean-Jacques, John Saunders, etc.

However, we suppose, that the insufficient process of the creation and implementation of the development strategy of the medical organizations in the medical sphere, the need for some methodical study of the matters of formation, effective introduction and improvement of the development strategy demand some additional consideration and carrying out the research in the field.

\section{State of the art and possible scenarios}

From the point of view of ensuring the worthy standard of living of Russian citizens, the medical sphere is one of the key ones as it creates the conditions for rendering high-quality medical care [4-6]. The level of development of the medical sphere determines the level of social development of the country. The demand for medical services is directly determined by the state policy in the field of health care and by the opportunity and readiness of the population to respect the rules of a healthy lifestyle.

The Russian market of medical services has obviously positive dynamics. Since 2010 there is a continuous increase in the medical sphere financing. According to the forecasts of the Ministry of Health of the Russian Federation the tendency to financing growth is positive, up to 2020 (fig. 1) that is caused by the existence of considerable financial opportunities and by the need of modernization of the medical sphere.

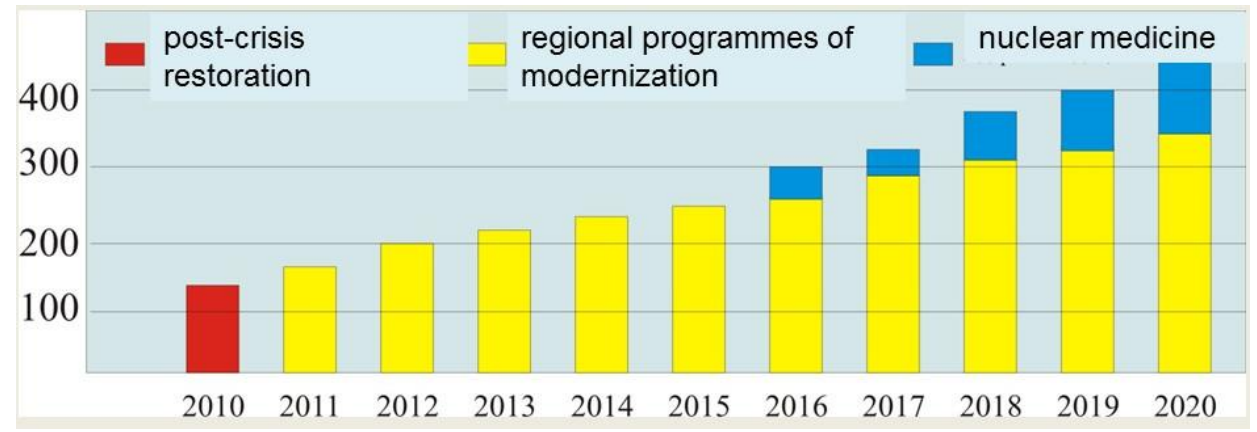

Fig. 1. Forecast of change of market volume, (billion roubles).

The medical organizations in Russia are characterized by low extent of consolidation and by the absence of large companies, which would possess sufficient equity for dynamic development and for the entry into foreign markets. The technological weakness and outdated technologies form the lag between the national medical organizations and foreign competitors. As a result, the Russian organizations do not enter the competition to the foreign organizations in fact.

The author considers it necessary to point out some system problems in the medical sphere in Russia.

The historical causes and aggravation of the system problems are in many respects connected with the system crisis of the Soviet economic system, which is felt until now and which has caused: 
- the collapse of the providing branches, closing of productions of special sorts of still, electronic components specialized (biologically inert and non-toxic) materials, precision products, etc.;

- termination of financing and almost full stop of science research and development, disorder of profile scientific institutions.

The key system problems of the Russian medical sphere can be formulated as follows:

- Technological backwardness.

- Dissociation.

- Poor innovative environment.

- Closeness, poor integration into the international markets.

The existence of the previously mentioned problems does not allow coming to a steady trajectory of growth of the domestic industry [7, 8]. Actually, for many segments of the market it is necessary to speak not about development of already existing potential of the modern medical sphere but about its creation.

It is possible to carry out modelling of perspective development of the medical sphere in the Russian Federation until 2020.

The long-term social-and-economic development of the medical sphere in the Russian Federation allows formulating inertial, investment and innovative scenarios of development $[9,10,11]$. Implementation of the inertial scenario, which is characterized by preservation of the current tendencies of development of the medical sphere, will lead to final stagnation of the Russian production and further replacement of the domestic medical organizations from the internal and external markets because of moral obsolescence of technologies and because the lack of system of its advance. Successful implementation of the investment scenario, which is characterized by emphasis on formation of modern production sites and adaptation of relevant foreign technologies in the territory of the Russian Federation, is hardly realistic in the field of medical services and it will only lead to a short-term increase in the local share of the domestic market. According to the innovative scenario, it is supposed that Russia will manage to develop the country's own technologies, competitive at the world level. However, the weakness of the base in the medical sphere, the lack of clusters and production cooperation will not allow to carry out domestic production of services fully. The need of overcoming these obstacles forms the main objectives for the implementation of the development strategy [12, 13, 14].

Table 1. Approaches and scenarios of creation and implementation of development strategies for the medical organizations.

\begin{tabular}{|c|c|c|c|c|}
\hline Approaches & Scenarios & \multicolumn{2}{|c|}{ Strategic alternatives } \\
\hline $\begin{array}{c}\text { General development } \\
\text { of the organization }\end{array}$ & All-corporate strategy & Narrow specialization & $\begin{array}{c}\text { Diversification into } \\
\text { related branches }\end{array}$ & $\begin{array}{c}\text { Non-core } \\
\text { diversification }\end{array}$ \\
\hline $\begin{array}{c}\text { Providing the } \\
\text { competitive } \\
\text { advantages }\end{array}$ & $\begin{array}{c}\text { Strategy of creation of } \\
\text { competitive } \\
\text { advantages }\end{array}$ & $\begin{array}{c}\text { Leadership in } \\
\text { expenses }\end{array}$ & Differentiation & Focusing \\
\hline $\begin{array}{c}\text { Activation of the } \\
\text { innovative activity }\end{array}$ & $\begin{array}{c}\text { Strategy in the } \\
\text { innovative sphere }\end{array}$ & $\begin{array}{c}\text { Technological and } \\
\text { market leadership }\end{array}$ & $\begin{array}{c}\text { Following for the } \\
\text { leader }\end{array}$ & Imitation \\
\hline
\end{tabular}

Thus, the choice of the scenario of development has to consider both the available material resources, and possibilities of all the subjects of the market of the transition to the innovative way [15]. At the same time, it is important that the main phase of the state investments into modernization of the Healthcare System was carried out until 2016. It sets the tasks of the import substitution for the health care. Therefore, the optimal variant is the development mainly according to the investment scenario (until the end of 2017) with the consecutive exit to the innovative direction by 2018-2020 [16]. 


\section{Results}

The analysis of the situation proved, that the process of creation and implementation of the development strategy of the medical organizations happens under the influence of many factors. It is necessary to find out the most significant factors of uncertainty for the medical organizations (table 2).

Table 2. Factors of uncertainty of the environment, influencing the medical organizations activity.

\begin{tabular}{|c|c|}
\hline \multicolumn{2}{|c|}{ Internal environment } \\
\hline \multicolumn{2}{|c|}{ production (limitation of resources, accidents, refusal and breakages of the equipment); } \\
\hline \multicolumn{2}{|c|}{ marketing (consumer and solvent demand); } \\
\hline \multicolumn{2}{|c|}{ finances (receivables amount, financial stability); } \\
\hline \multicolumn{2}{|c|}{ organizational structure (contradiction of interests of different levels of hierarchy); } \\
\hline \multicolumn{2}{|c|}{$\begin{array}{l}\text { human resource management (decision-making by managers - limitation of conscious activity, } \\
\text { inappropriate qualification); }\end{array}$} \\
\hline \multicolumn{2}{|c|}{ balance of the main components. } \\
\hline \multicolumn{2}{|c|}{ External environment } \\
\hline macro environment & micro environment \\
\hline $\begin{array}{l}\text { macroeconomic parameters (growth rate } \\
\text { GDP, inflation, etc.); }\end{array}$ & $\begin{array}{l}\text { capacity and tendencies of the market } \\
\text { development; }\end{array}$ \\
\hline technical and technological innovations; & intensity of the competition; \\
\hline $\begin{array}{l}\text { government policy (export/import, wars, } \\
\text { disorders, crises); }\end{array}$ & ways of services advance; \\
\hline natural disasters; & $\begin{array}{c}\text { suppliers of a human labour force, materials, } \\
\text { capital (prices, volume and frequency of } \\
\text { deliveries); }\end{array}$ \\
\hline $\begin{array}{l}\text { ecological situation (acceptance more } \\
\text { strict requirements, introduction of new } \\
\text { sanitary standards); }\end{array}$ & consumers; \\
\hline shifts in public demands; & creditor \\
\hline standard of living; & public authorities; \\
\hline legislation; & clients (change of preferences); \\
\hline $\begin{array}{l}\text { credit and financial policy (exchange rate, } \\
\text { taxes, credits, privileges); }\end{array}$ & intermediaries (delay of payments); \\
\hline demographic situation. & $\begin{array}{l}\text { interest rates of commercial banks } \\
\text { for the credits, percent of banks for deposits; }\end{array}$ \\
\hline & substitute goods; \\
\hline & con \\
\hline
\end{tabular}

In practice, there are no clear and systematic recommendations, concrete directives on the organization of process of implementation of the development strategy. Various organizations in the medical sphere significantly differ because of the infinite variety of the internal environment, or because of the variety of strategic situations in the external environment. Dynamic conditions of the competition and various experience, the unstable environment and alternative ways of development of the organization, the unique organizational culture and its own policy, systems of motivation predetermine the individual approach to implementation of the development strategy [17-21].

At the same time, the accumulated experience and the analysis of information on this matter allow to predict the opportunity of pointing out some fundamental elements (stages) of the process of introduction of the development strategy (fig. 2). 


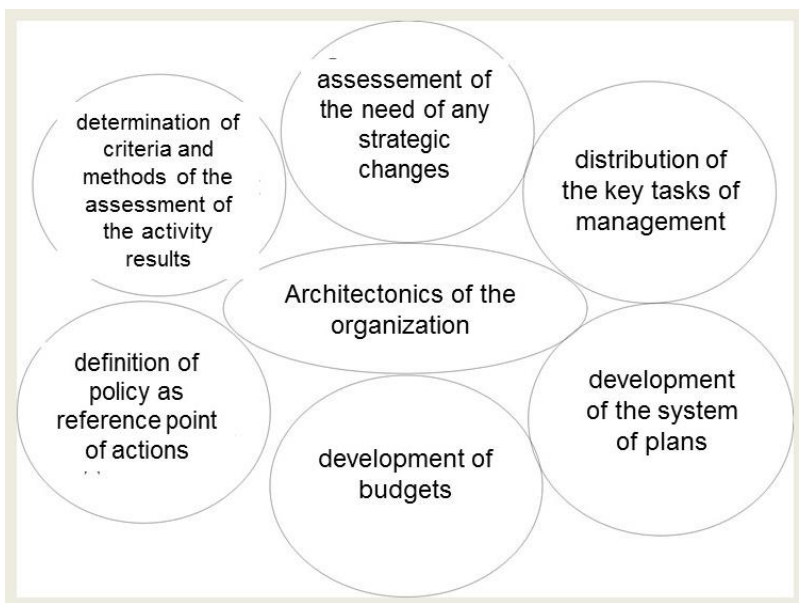

Fig. 2. Main conditions of creation and implementation of the development strategy of the medical organizations.

\section{Discussion}

In spite of the fact that there are no unambiguous recommendations, some concrete directives about the organization of process of implementation of the development strategy, experts discuss some strategies for the organizations in the medical sphere. The most successful strategies are presented in Table $3[16,17]$.

Table 3. The optimum strategies offered for the development of the medical organizations.

\begin{tabular}{|c|c|c|}
\hline Functional strategy & $\begin{array}{c}\text { The measures plan of a separate functional division (functional zone) in a } \\
\text { business unit (the organization included into the corporation) }\end{array}$ \\
\hline $\begin{array}{c}\text { production } \\
\text { (operating) strategy }\end{array}$ & $\begin{array}{c}\text { Measures of the medical organization are aimed on management of the main } \\
\text { structural divisions (the sphere of developments, production divisions, sales } \\
\text { department, purchasing department) while solving the current operational tasks, } \\
\text { which have strategic importance. }\end{array}$ \\
\hline $\begin{array}{c}\text { strategy of } \\
\text { leadership in } \\
\text { expenses }\end{array}$ & $\begin{array}{r}\text { It is connected with the orientation of production to the high-quality services and its } \\
\text { realization at rather low prices. }\end{array}$ \\
\hline $\begin{array}{c}\text { strategy of focusing } \\
\text { It is connected with concentration of efforts in the limited area, where the medical } \\
\text { organization has a clear competitive advantage for the achievement of the } \\
\text { predominating position in the narrow segment of the market chosen. }\end{array}$ \\
\hline $\begin{array}{c}\text { strategy of a market } \\
\text { niche }\end{array}$ & $\begin{array}{r}\text { Measures of the medical organization are aimed on finding not big, but rather } \\
\text { attractive segment of the market where specific inquiries prevail. }\end{array}$ \\
\hline
\end{tabular}

\section{Conclusion}

As the result of the analysis of the problems of creation and implementation of the development strategy for the medical organizations, the author has developed her offers and recommendations. The author considers, that as practical application of creation and 
implementation of the development strategy for the studied organizations in the medical sphere the following development strategies will be the most efficient:

- functional strategy;

- production (operating room) strategy;

- strategy of leadership in expenses;

- strategy of focusing;

- strategy of a market niche.

\section{References}

1. A. Trushkin, L. Demyanova, N. Malakhova, Economics and management in health care (Phoenix, Moscow, 2015)

2. E. Vasilyeva, I. Polyakova, MATEC Web of Conferences 106, 08097 (2017)

3. As. Mottaeva, MATEC Web of Conferences 106, 08072 (2017)

4. E. Akimova, G. Potasheva, MATEC Web of Conferences 106, 08080 (2017)

5. N. Khan, Financial model of health care (Business, Moscow, 2013)

6. A guidebook of Projekt\&Program Management For Enterprise Innovation (PMCC/ENNA, Japan, 2012)

7. E. Vasilyeva, A. Zlentenkov, O. Suzneva, E. Sapozhnikova, IOP (Earth and Environmental Science) 90, 12122 (2017)

8. T. Tereshkina, A. Mottaeva, L. Andreeva, T. Larinina, IOP Conference Series: Earth and Environmental Science. Energy Management of Municipal Transportation Facilities and Transport, EMMFT 2017" 19, 012138 (2017)

9. D. Russel, Managing of High-Technology Programs and Projects (John Wileg \& Sons Inc., New York, 2012)

10. A. Mottaeva, As. Mottaeva, International Journal of Applied Engineering Research 11(9), 6808-6816 (2016)

11. S. Thomson, Financing health care in the European Union: challenges and policy responses (World Health Organization on behalf of the European Observatory on Health Systems and Policies, EU, 2009)

12. A. Mottaeva, As. Mottaeva, International Journal of Applied Engineering Research 10(23), 43446-43449 (2015)

13. M. Meskon, A. Hedouri, Management bases (Business, Moscow, 2012)

14. B. Milner, Theory of the organizations (INFRA-M, Moscow, 2016)

15. A. Mottaeva, A. Zheltenkov, E3S Web of Conferences 33, 01038 (2018)

16. E. Vasilyeva, V. Okrepilov, E3S Web of Conferences 33, 03048 (2018)

17. V. Paris, M. Devaux, L. Wei, OECD Health Working Papers, 50 (2010)

18. A. Mottaeva, As. Mottaeva, International Journal of Applied Engineering Research 6(2), 256-262 (2016)

19. I. V. Ilin, A. Lepekhin, A.I. Levina, O Yu. Iliashenko, Advances in Intelligent Systems and Computing, 692, 1306-1314 (2018) DOi -10.1007/978-3-319-70987-1_138

20. I. V. Ilin, A.I. Levina, O Yu. Iliashenko, MATEC Web of Conferences, 106, 08066 (2017) DOi-10.1051/matecconf/201710608066

21. V. V. Gluhov, I. V. Ilin, Lecture Notes in Computer Science, 8638, 509- 518 (2014)

DOi-10.1007/978-3-319-10353-2_46 